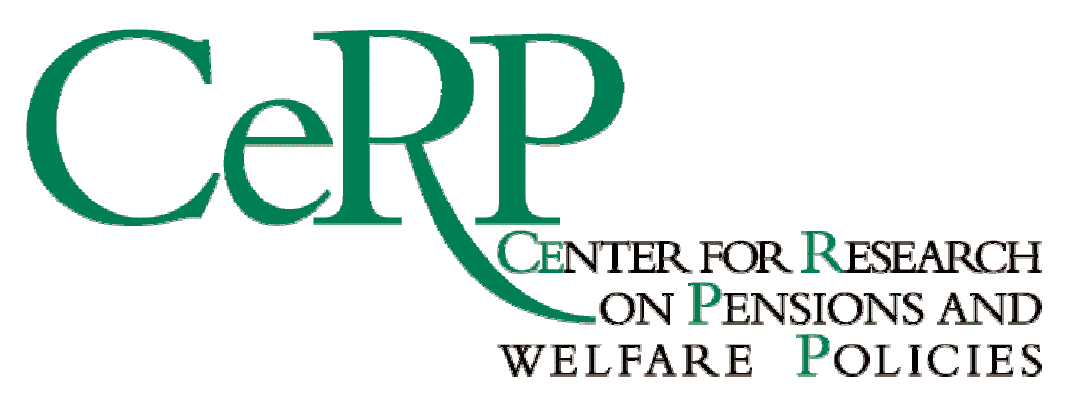

Working Paper 17/02

\title{
THE LABOUR SUPPLY EFFECT OF THE ABOLITION OF THE EARNINGS RULE FOR OLDER WORKERS IN THE UNITED KINGDOM
}

\author{
Richard Disney \\ Sarah Smith
}

\footnotetext{
${ }^{*}$ University of Nottingham, and Institute for Fiscal Studies, London. Corresponding author: School of Economics, University of Nottingham, NG7 2RD, UK; email: richard.disney@nottingham.ac.uk

${ }^{\dagger}$ Financial Services Authority
} 


\title{
THE LABOUR SUPPLY EFFECT OF THE ABOLITION OF THE EARNINGS RULE FOR OLDER WORKERS IN THE UNITED KINGDOM
}

\author{
by \\ Richard Disney* $^{*} \quad$ and $\quad$ Sarah Smith $^{\dagger} \square$
}

\begin{abstract}
High effective tax rates on work at and around state pension age deter participation. An example is the 'earnings test' operating in several OECD countries. The United States abolished its test for the 65+ age group in 2000. The United Kingdom offers a 'natural experiment' of this reform, as it abolished its test, known as the 'earnings rule', in 1989. We examine the effect of this change, taking account of the opportunity to defer pension rights. Abolition of the rule raised working hours of older male workers by around 4 hours a week, with a lesser impact on women's behaviour.
\end{abstract}

JEL Classification: J22 J26

Key Words: Labour supply; Retirement; Earnings Test

\section{Acknowledgements}

Funding for this research has been provided by the ESRC Centre for the Microeconomic Analysis of Fiscal Policy. Material from the Family Expenditure Survey was made available by the ONS through the ESRC Data Archive and has been used by permission of the controller of ONS. The authors wish to thank two referees, Richard Blundell, Barry Bosworth, Gary Burtless, Bill Gale, Amanda Gosling, Jon Gruber, Richard Johnson, Costas Meghir, John van Reenen, Edward Whitehouse and other seminar and workshop participants at IFS, the IMF, the University of Manchester, a TMR Savings and Pensions conference and the World Bank for comments. The normal disclaimer applies. In addition, the Financial Services Authority is not responsible for any views expressed here. 


\section{THE LABOUR SUPPLY EFFECT OF THE ABOLITION OF THE EARNINGS RULE FOR OLDER WORKERS IN THE UNITED KINGDOM}

\section{Introduction}

The decline in hours of paid work among the elderly, primarily among older men, in OECD countries is well documented (for example, OECD, 1996) The United Kingdom is no exception to this trend - see, for example, Blundell and Johnson (1999) and Disney (1999). An influential school of thought links this decline, and the relative speed of decline in different countries, to the magnitude of effective taxes on remaining in work for older people (Gruber and Wise, 1999). Reduce these effective taxes, it is argued, and workers will defer retirement until a later date.

A particularly extreme version of a tax on older workers are the earnings tests which operate in a number of OECD countries. ${ }^{1} \square_{\text {These restrict the amount of state }}$ pension that can be received by people who continue to work past pensionable age, by withdrawing the pension in line with earnings at high marginal rates. Table 1 depicts the nature of these tests for OECD countries. As can be seen, there is a wide variety of practice, from environments where it is basically impossible simultaneously to work and to receive a public pension (such as Ireland, Portugal and Spain) through to regimes where earnings can be received without extra penalty (of course, such countries will still typically levy income tax and, in some cases, payroll taxes on postretirement earnings). Note also that many countries which operate such tests also disregard a certain level of earnings in applying the test, and that some countries also permit individuals to defer their pension, with a higher rate of pension being paid 
when the individual finally stops working, reducing the test's effective penalty on working beyond pension age.

\section{$<$ Table 1 here $>$}

The earnings test has received particular prominence recently, with the United States abandoning the application of its test to people aged over 65 from 2000, with the general aim of increasing hours of work of older people. ${ }^{2}$ The debate preceding the reform generated a certain amount of empirical work designed to simulate the impact of the policy. The United Kingdom, however, offers a 'natural experiment' by which the effect of such a change can be examined, since it abolished its own earnings test, known as the 'earnings rule' in 1989 (Whitehouse, 1990). A sufficient time interval has elapsed to permit a proper evaluation of the impact of this change. The purpose of the present paper, therefore, is to estimate the impact of the abolition of the earnings rule in the United Kingdom on the hours of work of older workers, comparing our findings with simulations of similar changes both in the UK and elsewhere and with one actual study of an abolition, for Canada.

The structure of the remainder of the paper is as follows. Section 2 summarises the operation of the earnings rule in the UK up to 1989 and describes other studies of earnings tests both in the UK and elsewhere. Section 3 writes down a simple formal model of the joint decisions concerning retirement and deferral facing an individual. Section 4 provides empirical evidence on the impact of abolition and provides a brief conclusion. 


\section{Earnings Tests: basics and empirical methods}

\subsection{The basics of the earnings test}

The imposition of an earnings test generates a highly non-linear static budget constraint facing workers on reaching pensionable age. Fig. 1 illustrates a budget constraint that exhibits the main features of the 'earnings rule' as it operated in the United Kingdom until 1989. It assumes a wage rate of $£ 3.50$ an hour, a basic state pension of $£ 44$ per week (the level in 1989), a tax rate, net of the age allowance (assumed equal to the basic pension), of $25 \%$ and an earnings rule operating in the following manner: gross earnings of $£ 75$ per week are exempt, the basic pension is withdrawn at 50 pence per $£$ of earnings from $£ 75$ up to $£ 79$, and $£$ for $£$ thereafter.

$$
<\text { Fig. } 1 \text { here }>
$$

As Fig. 1 demonstrates, the static budget constraint exhibits a convex kink at the exempt amount (the earnings disregard) at point B and a non-convex kink where the state pension entitlement is exhausted, at point C. Friedberg (1998) provides illustrations of the very similar US earnings test, and there are also parallels with the operation of other benefit regimes, notably those for in-work benefits to low income families such as the Working Family Tax Credit in the UK (Blundell et al, 2000) and the Earned Income Tax Credit in the US (Eissa and Liebman, 1996).

In the simplest interpretation, abolition of the earnings rule linearises the budget constraint, as indicated by the dotted line in Fig. 1. Basic labour supply theory would then suggest no change in hours for non-participants at point $\mathrm{A}$ or for participants between points A and B, a potentially large increase in hours supplied by individuals bunched at the kink point $\mathrm{B}$, and a possible negative impact on hours of 
those had previously worked at some point above $\mathrm{C}$. $\mathrm{On}$ balance, however, the net effect of these changes, although depending on the overall distribution of hours, might be positive, especially where hours are organised in discrete 'packages' of part-time and full-time work (Hurd, 1996). Specifically, abolition of the earnings rule might encourage individuals who had gone part-time at state pension age in order to avoid the impact of the rule to choose instead to remain in full time work for a longer period.

There are, however, complications arising from the earnings rule. First, individuals in the United Kingdom had, and still have, the opportunity to defer pension receipt. The earnings rule operated for five years after state pension age (65 for men, 60 for women) until state 'retirement age' (70 for men, 65 for women). Anyone could choose to defer receipt of the state pension for up to five years and thereby accrue additional pension entitlements at a rate of $7.5 \%$ (in 1989) for each year that they deferred. ${ }^{5}$ This rate is approximately actuarially unfair for a single man and actuarially favourable for a single woman, given life expectancies of respectively 14.3 years at 65 for a man and 22.1 years at 60 for a women, although one should also take account of time discounting, the inheritance of deceased spouse's benefits, and the likelihood of self-selection of deferrers on the basis of individual differences in expected longevity. Note that deferral requires an explicit decision in the UK, whereas in the US, benefits in each year after normal retirement age are automatically increased by $6.67 \%$ for each year of full benefits lost due to the earnings test through the Delayed Retirement Credit (Gruber and Orszag, 2000). In Fig. 1, actuarially unfair deferral is illustrated by the bold dashed line. For such people who chose to defer, abolition of the earnings rule should act as a pure positive income effect, which should, on balance, reduce their hours of work. 
The other complication concerns couples versus single people. Reforms of this kind may also affect spouses' behaviour, especially where one partner is over state pensionable age and the other is below. For example, abolition of the earnings rule might induce the older partner to continue in full time work rather than switch to part time work, which might in turn affect the hours or participation decision of the younger partner.

\subsection{Previous research on earnings tests}

In contrast with other areas of labour supply, the literature on earnings tests and older workers is limited. Moreover, much of the literature does not adequately take adequate account of the deferral option or of the problem of handling the behaviour of spouses. The traditional approach in the United States, exemplified by Burtless and Moffitt (1985), utilises a piecewise linear budget constraint approach to estimate labour supply effects of the earnings test in the US for an individual worker. Typically, such studies conclude that the test has had little effect on labour supply (for a survey, see Leonesio, 1990).

A criticism of such studies, noted by Friedberg (2000) is that, in the absence of temporal variations in the tax structure (i.e. changes in the disregards, tax rates or even outright abolition of the earnings test), estimates depend on cross sectional variation in components of income such as the wage rate and unearned income. If these correlate with unobservables, then the estimated effects will be biased. Gustman and Steinmeier's study (1986) may be subject to the same criticism concerning unobservables, but an added reason for their finding of a relatively small effect lies in their attempt to model the impact of the Delayed Retirement Credit in a 
structural retirement model which, as we suggested previously, should alleviate the impact of the test. The idea that an earnings test might affect the timing of the first claim on social security benefit is explored by Gruber and Orszag (2000) who argue that abolition of the test might accelerate the first claim on social security, so reducing labour supply in total irrespective of the behaviour of those round the kink (i.e. point B in Fig. 1).

A further criticism of quasi-structural estimation of the model (at least of its static component) arises from the use of the piecewise linear budget constraint method itself. MaCurdy, Green and Paarsch (1990) argue that the log likelihood is only defined for individuals locating at a kink like point B in Fig. 1 if the compensated substitution effect is positive. Thus there is an inherent bias in the method towards finding positive compensated substitution effects. Blundell et al (1998) circumvent this issue in another context by dropping observations at the kink and estimating labour supply elasticities over the rest of the sample, selectivity corrected. As Friedberg (2000) points out, however, their procedure is unappealing in the context of the earnings test since much of the 'action' is expected to derive precisely from the behaviour of those at the kink. Her own estimates by the piecewise linear budget constraint method, she argues, do not require the imposition of a positive compensated substitution effect and avoid the issue of correlation with unobservables by exploiting temporal variations in both the level of the disregard (exempt amount) to the earnings test and changes in the effective tax rate, between 1978 and 1990. She utilises the resulting elasticities to estimate that abolition of the earnings test in the US would raise hours worked of those at or above the kink at point B by $5.3 \%$. Put simply, this would raise the hours of a part timer working 20 hours a week by one hour. 
However Friedberg's work is also not immune from criticism. The first is that the 'dynamic' aspect of the issue - the accrual of Delayed Retirement Credit (DRC) from any tax levied as a result of the earnings test - is simply ignored on the grounds that people do not understand the DRC. Effectively, it is assumed that individuals are sophisticated enough to adjust their labour supply to small variations in exempt amounts and effective tax rates while systematically disregarding the fact that tax levied will be recovered later through higher pension benefits. Second, there is always danger in extending marginal elasticities derived from small changes to construct hypothetical outcomes for large changes, such as the abolition of a whole tax regime.

The only previous study of the earnings rule in the UK is contained in a pathbreaking study by Zabalza et al (1980). They utilised data for a cross-section of people aged between 50 and 73 in 1977 to develop a discrete tri-choice model in which individuals could choose between full-time and part-time work, and nonparticipation. By imposing a CES utility function and requiring convexity of the opportunity set in the ordering full-time, part-time, non-participation, they were able to predict chosen states ( $78 \%$ of the time) and to use parameter estimates to simulate policy changes. Specifically, abolition of the earnings rule would leave participation unaffected, but raised the average hours worked (averaged over all people) by about $2 \%$ for men and $1.6 \%$ for women. Since roughly $20 \%$ of people in the relevant age range worked in the late 1970s, this gives somewhat larger magnitudes than Friedberg's estimates.

Zabalza et al may however overstate the success of their model. Since the age range is fairly broad, predictive power is achieved largely by predicting that people under pension age work and that the majority of older people over pension age do not work. Only $10 \%$ of actual part-time workers (amongst whom are those at the kink at 
point B in Fig. 1) are successfully predicted by their model. Consequently, the simulated shift from part-time to full-time work arising from the abolition of the earnings rule must have a very high standard error.

What characterises all these studies is that they rely on simulated responses derived from labour supply modelling, although Friedberg (2000), like Blundell et al (1998), exploits policy variation to identify elements of model structure. A different empirical strategy is to look at actual reforms - in this case, actual abolition of earnings tests - to estimate policy effects. A standard approach in this case uses 'differences of differences', which requires finding a 'control group' who are unaffected by the reform in question and who are affected identically by other 'shocks' (for example, to labour demand). This is the approach used here. It is surveyed by Angrist and Krueger (1999) and utilised in a number of comparable policy experiments concerning tax regimes.

Only one study, to our knowledge, applies the method to an earnings test. Baker and Benjamin (1999) examine the sequential elimination of earnings tests from pension plans in Canada in the mid-1970s. They exploit the fact that the Quebec Pension Plan and the (rest of) Canada Pension Plan abolished their earnings tests at different times, so giving an overidentifying test. Moreover, there was no equivalent to the Delayed Retirement Credit in the US to complicate the picture: taxed away benefits were simply lost. ${ }^{8}{ }^{\square}$ This gives a potentially clean test of the impact. Baker and Benjamin find no evidence that abolition of the tests affected participation, some evidence that take-up of benefits was affected and, most pertinently, some evidence of a shift from part-time to full-time work. However this shift in general took the form of a shift in the number of weeks worked per year ( +5 to 6 weeks) rather than a shift in hours per week. They argue that this result is consistent with a discrete shift fixed- 
hours of work model, as described by Hurd (1996), rather than incremental changes in hours around Point B in Fig. 1.

\section{Modelling retirement and deferral decisions with the UK earnings test}

To analyse the problem, consider a simple two-period decision environment at state pensionable age. In the first period the individual decides whether to (continue to) work and whether to receive the flat state pension - yielding three possible options. He or she can retire immediately and start drawing the state pension. He or she can carry on working and defer pension receipt. Or else (s)he can carry on working, and start drawing the pension, in which case (s)he might be subject to the earnings rule. In the second period, the individual receives a flat-rate pension, the value of which is conditional on the choice made in the first period.

Assume a general utility function:

$$
\mathrm{U}=\mathrm{U}\left(\mathrm{c}_{1}, 1_{1} ; \beta \mathrm{c}_{2}, \beta 1_{2} \mid \theta\right) \quad \mathrm{U}_{\mathrm{c}(\mathrm{)})}>0, \mathrm{U}_{1(.)}>0
$$

where $\mathrm{c}$ is consumption and 1 is leisure (indexed by period), $\beta$ is an individual discount factor $(0<\beta<1)$ and $\theta$ is the (individual-specific) probability of surviving until the second period. ${ }^{1}$

We now write the budget constraint for the two period remaining lifetime, Y, for different options. If the individual retires immediately, total income is given by;

$$
\text { (1) } Y=p+\theta p
$$

where $p$ is the flat (basic) pension.

If (s)he decides to continue to work and defer pension receipt, income is given by; 
(2) $\quad \mathrm{Y}=\mathrm{w}(1-\mathrm{t})+\theta \mathrm{p}(1+\mathrm{r})$

where $\mathrm{r}$ is the adjustment of the pension arising from deferral and $\mathrm{t}$ is the average rate of tax which is payable when the individual is working but not when (s)he is retired. If (s)he works but does not defer pension receipt, total income is:
(3) $Y=w^{*}+\theta p$ where
(3i) $\quad \mathrm{w}^{*}=(\mathrm{w}+\mathrm{p})(1-\mathrm{t})$ if $\mathrm{w}<\mathrm{w}_{0}$
(3ii) $\quad \mathrm{w}^{*}=\left(\mathrm{w}_{0}+\mathrm{p}\right)(1-\mathrm{t})$ if $\mathrm{w}_{0} \leq \mathrm{w}<\mathrm{w}_{0}+\mathrm{p}$
(3iii) $\mathrm{w}^{*}=\mathrm{w}(1-\mathrm{t})$ if $\mathrm{w} \geq \mathrm{w}_{0}+\mathrm{p}$

where the non-linearity in the wage outcome reflects the operation of the earnings rule.

Faced with these different possibilities, what would an individual choose to do? Certain options can be eliminated fairly easily. For example, the individual would always choose 3(i) over 3(ii) since in the latter case $\partial w^{*} / \partial w=0$. So we might expect to see a 'bunching' of individuals at the kink point $\mathrm{w}_{0}$ (point $\mathrm{B}$ in Fig. 1). Also, a forward-looking individual should always choose (2) over 3(iii) since the former augments the pension in period 2 by $r$. This reduces the effective choice to (1), (2) and 3(i). The actual decision will depend on the relative utility from leisure and consumption, the discount rate, the survival probability, the income tax rate and the deferral rate. These last four factors determine whether deferral is actuarially fair. For someone working, this requires that $(1-t)=\theta r$, although assuming $\beta<1$ implies that an individual will require an actuarially favourable deferral rate in order to postpone 
retirement. Note that the tax system tends to favour deferral since all of the pension is likely to be taxed if the individual receives it now in addition to his or her earnings.

It is possible to distinguish four types of people.

- Type $1 \mathrm{~s}$ retire and start drawing their pension in period one. They are likely to derive high utility from leisure relative to additional income and deferral is more likely to be actuarially unfavourable for them.

- Type 2 s choose to work and earn at or less than the earnings test limit and start drawing their pension immediately. For them deferral is likely to be actuarially unfavourable and they derive relatively lower utility from any increased income they could get earning more than the earnings rule threshold.

- Type 3s are those who work and defer pension and for whom deferral is actuarially favourable.

- Type $4 \mathrm{~s}$ are those who work and defer and for whom deferral is actuarially unfavourable, but who derive high utility from income relative to leisure and are therefore prepared to pay the tax implicit in deferral. Note, however, that the penalty they pay for earning above the earnings rule threshold is less than if there were no deferral option when they would lose $\theta$ pr in the second period.

If the earnings test is abolished, (3) becomes;

$$
\mathrm{Y}=(\mathrm{w}+\mathrm{p})(1-\mathrm{t})+\theta \mathrm{p}
$$

How does this affect the four types? Type 1s and Types 3s will be unaffected. Type $2 \mathrm{~s}$ will tend to work more following the abolition of the earnings rule. They will have an incentive to increase their hours and earnings since $\partial \mathrm{Y} / \partial \mathrm{w}>0$. Type $4 \mathrm{~s}$, for 
whom deferral is actuarially unfavourable, will no longer have to defer if the earnings rule is abolished. As a result they will experience a positive income effect and could choose to reduce the number of hours worked.

A priori the impact of abolishing the earnings rule on work incentives depends on the relative numbers of Type $2 \mathrm{~s}$ and Type $4 \mathrm{~s}$, and on the size of the implicit tax rate facing Type $4 \mathrm{~s}$ who chose to defer when the earnings rule was in place. At the time of abolition, the government claimed that around 400,000 people would gain as a result (see Whitehouse, 1990). This total included 200,000 people who would choose to work and earn more and 200,000 who would gain because they would no longer have to defer their pension. Taken literally, the official figures imply a fairly equal split between Type $2 \mathrm{~s}$, who would work more following the abolition of the earnings rule, and Type $4 \mathrm{~s}$ who were previously deferring at an actuarially unfair rate and who might choose to work less after the abolition of the earnings rule. In fact this 200,000 figure for the number of people who would gain from no longer having to defer their pension seems too high. It is closer to the total number of deferrers at the time of the change and will therefore include some people of Type 3.

What of married women? Given their longer life expectancy, women are more likely than men to be Types 3s, suggesting a gender-specific impact from abolition of the earnings rule. But the position is complicated by the fact that, before 1978, married women could opt to pay a reduced rate of National Insurance contribution, which meant that they did not qualify for a basic state pension in their own right. However couples in which one partner did not qualify would receive a dependant's addition. So married women may have been indirectly affected by the reform through its effect on their spouses' behaviour. 
Again, there are several cases. The first case is women married to Type 2 men, i.e. men who are likely to increase their hours as a result of the earnings rule being abolished. This will cause a positive income effect for the wife who, if she is working, is likely to reduce her hours - or stop working altogether. The second and third cases are both women married to Type 4 men, i.e. those for whom deferral is actuarially unfair and who choose to start drawing their pension once the earnings rule is abolished. The distinction lies in whether the husband takes account of the lifetime of the couple in assessing whether deferral would be actuarially unfair, or only their own lifetime. If the former, then abolishing the earnings rule and allowing the husband to draw the pension immediately will have a positive income effect for both spouses. If the latter, then there may be some wives who experience a fall in their total incomes following the abolition of the earnings rule if their husbands choose not to defer. For members of this third group the abolition of the earnings rule has a negative income effect which could cause them to increase their hours of work. If they do not, then abolition of the earnings rule could in the longer term, generate higher levels of poverty among elderly widows. Overall, we might expect to find less clear cut results for women than for men.

\section{Empirical estimates}

To evaluate the effect of abolishing the earnings rule, we compare any change in hours and earnings of men aged 65-69 and women aged 60-64 before and after the reform with the change in the same variables over the same period of two comparison groups. The first consists of men and women five years before state pension age (i.e. men aged 60-64 and women aged 55-59) who remained ineligible for the state pension throughout. The second consists of older men aged 70-74 and women aged 
65-69 who could receive the state pension without being subject to earnings rule throughout. The purpose of the comparison groups is to control for the potential effect of macro-factors on hours and earnings before and after the reform.

To identify the effect of the reform from a differences-in-differences approach, two conditions must be satisfied (Angrist and Krueger, 1999). First, the composition of the groups must be stable across time and second, the control and treatment group must be subject to (and react in the same way to) macro trends. The first condition is potentially violated if there are any spillover effects from the reform to the control groups. This is a potential problem with members of the younger control group who might change their labour market behaviour in anticipation of no longer having to face the earnings rule when they reach state pension age. The effect on labour supply could go either way. If there are significant tenure effects then abolition of the earnings rule might create a stronger incentive for younger workers to work now. Any positive income effect would tend to work in the other direction.

A second potential problem with the younger control group is that the balance between full-time and part-time workers is quite different in the younger male cohort compared to the treatment group and is much more similar in the treatment group and the older cohort. Since full-time and part-time workers might be differentially affected by macro factors, this also will tend to make the younger cohort a less valid control. Nevertheless, because of relatively small sample sizes for the older control group, we present results for both the older group and for the older and younger control groups combined. 4

The data set is the Family Expenditure Survey from April 1984 - March 1994. The FES contains reliable and consistent information on employment status, hours 
worked and earnings that allows us to look at employment before and after the abolition of the earnings rule, as well as information on individuals' state pension income that permits an assessment of the extent to which individuals defer pension receipt. Table 2 shows the sample sizes for the 'treatment' group and the two 'control' groups. Among the older age groups participation rates are very low and pooling across a number of years is necessary to increase sample sizes when looking at hours and earnings.

\section{$<$ Table 2 here $>$}

Fig. 2A plots the distribution of earnings (in constant 1989 prices, adjusted using an earnings index)for men aged 65-69 when the earnings rule was in place and after its abolition, for positive earnings. Fig. 2B presents the same data for women. We focus on the period after April 1986 since from this time the earnings rule thresholds were unchanged in nominal terms. The earnings rule did appear to have had some impact on earnings for men and women. The rule made some allowance for work-related costs, which will have had a smoothing effect on any potential 'kink' in the distribution of earnings at the threshold. Even so, we observe some bunching in the distribution of male and female earnings around the $£ 75$ threshold, although in neither case is the mass of the distribution to be found around these points. Interestingly, the largest spike in the distribution for men occurs around $£ 40$ a week, reflecting the Lower Earnings Limit for National Insurance contributions, even though employees over state pensionable age are not liable for National Insurance contributions. After abolition there is some evidence, from 'eye-balling' the distributions, of a reduction in the spike at $£ 75$ and of greater frequencies at higher earnings for both the male and female distributions. 
Table 3 summarizes participation and average hours for the treatment and control groups before and after abolition of the earnings rule. The only significant change in participation occurs for younger men. The fall in employment among this group - and the likely effect of this on the sample composition of workers in this age range - poses a further problem for using younger men as a control group. Note, however, the direction of the bias is likely to understate any impact of abolition of the earnings rule on participation, if the counterfactual would have been an equivalent reduction in participation among the treatment men.

In contrast, the evidence clearly suggests that the abolition of the earnings rule had a significant effect on the number of hours worked by men. A Wilcoxon ranksum test rejects the null that the pre and post-reform distributions are independent samples from populations with the same distribution (Table 3). The average number of hours worked by men in the treatment group increased significantly, by nearly four hours per worker, despite no significant change in average hours, or in the distribution of hours, among the older or younger cohort over the same period.

\section{$<$ Table 3 here $>$}

This is confirmed by regression analysis. We regress weekly hours for individuals in the three groups on a set of dummies for the treatment and younger control groups and a dummy for the period after the abolition of the earnings test. We include an interaction term that takes the value one for the treatment group in the post-reform period to pick up any differential change in the hours of this group after the reform relative to the two control groups. We use both OLS analysis and a Tobit; 
the latter to handle the left censoring of the data. The Tobit estimates are depicted here, although there is in fact little difference in the results using the two estimators.

The results for men are summarised in the first panel of Table 4. Combining the two control groups, there is a significant increase in the average number of weekly hours - around four hours a week - worked by members of the treatment group relative to the controls after the reform. Excluding the younger control group, there is still an increase of just over three hours a week, although the reduction in sample size increases the standard error.

\section{$<$ Table 4 here $>$}

Table 4 also shows the marginal effects from a probit regression on whether or not the individual works 40 or more hours a week. There is a significant increase in the proportion of men in the treatment group working more than 40 hours a week after the reform compared to the control group. This result strongly suggests that we are observing discrete shifts from part-time to full-time work, as conjectured by Zabalza et al (1980) and Baker and Benjamin (1999), rather than incremental adjustments of hours which, given the argument of Section 2, might be expected to reduce hours among those higher earners for whom the earnings rule abolition induces a notional positive income effect. 6

Finally, Table 4 summarises the results of a regression of earnings on the same variables and shows a positive and significant increase in the earnings of the treatment group after the reform compared when both control groups. Again, small sample size limits the significance of the comparison with the older control group. Note that the increase in earnings of the control group more than offsets a reduction in earnings in the post-abolition period across all groups. 
Table 5 replicates Table 4 for women. Similar results are obtained, although the coefficient estimates are lower. The abolition of the earnings test raises average hours by just over 2 hours a week, and average earnings by just over $£ 20$ per week, but these results disappear when the only the older control group are used, despite the larger sample size compared to men. A Wilcoxon rank-sum test fails to reject that the distribution of hours are the same before and after the reform, but the increase in the average number of hours worked among the treatment group is significant at the 5\% level.

$$
<\text { Table } 5 \text { here }>
$$

\subsection{Deferral}

There is little evidence of a reduction in hours among high earners caused by a positive income effect among people of type 4 (i.e. those who previously chose to work and defer at an actuarially unfair rate). One possible explanation is that for most people who chose to defer their pension, deferral was in fact actuarially favourable given their individual expected longevity. In this case, we would not expect to see a large fall in the number of people who chose to defer after the reform.

Fig. 3 shows cohort profiles of the proportion of men who received increments to their pension as a result of deferral, derived from published official statistics (DSS, Social Security Statistics, various years). The cohorts are defined according to the year in which people reach state pension age. The oldest cohort comprises those who reached 65 in 1980. At younger ages, the cohort profiles rise, reflecting an increasing number of the cohort who have retired after state pension age and who have begun to receive a deferred pension. The increase in observed deferrals at older ages is likely to reflect the effects of differential mortality, again suggesting that we are observing 
Type 3 rather than Type 4 people (in our earlier parlance). There is a gradual decline in deferral across successive cohorts, but there is however no evidence of a structural break after the abolition of the earnings rule. ${ }^{18}$

$<$ Fig. 3 here $>$

\section{Conclusions}

The a priori effect of abolishing earnings tests for social security on work incentives is ambiguous. People who are currently earning at or near the earnings test threshold are likely to have an incentive to work more. But a second group of people will experience a positive income effect as a result of abolishing the earnings test and this second group may actually reduce their hours and earnings. In practice, the option to defer pension receipt reduces the size of the penalty associated with earning above the earnings test threshold. Indeed if deferral were actuarially fair it would eliminate the penalty of the earnings test altogether - and any positive income effect arising from its abolition.

The earnings test, known as the earnings rule, was abolished in the UK in October 1989. Our estimates suggest the reform had a positive effect on the hours and earnings of men and women, although the net impact on women is lower, as our discussion of family responses would suggest. Among male participants in the affected age range there was an increase of between $3-4$ hours per week, and for women, perhaps 2 hours a week. To get some idea of the magnitude of this effect, an earnings response of this size would generate additional tax revenue for the government of around $£ 20$ million per year (in 1989 prices). 
There is no evidence of any reduction in hours that would arise as a result of a positive income effect from abolishing the earnings test. Our explanation for this finding is that most of those who chose to defer did so because, for them, deferral was actuarially favourable. Support for this hypothesis comes from the fact that there is little indication of a significant reduction in deferral after the earnings test was abolished.

Two caveats are in order. First, the younger control group is not ideal, and the results are much weaker when only the older control group is used, given its small sample size. Second, the 'differences of differences' approach used here does not permit any structural modelling, in particular of the decision to participate (not to retire) and how many hours to supply conditional on participation. An obvious step forward, given the clean test offered by the UK experience, would be nest the policy 'experiment' within a structural approach to labour supply. This is task of current research. 
Table 1. Earnings Tests in OECD countries

\begin{tabular}{|c|c|c|}
\hline & $\begin{array}{c}\text { Disregard } \\
\text { \% of average earnings) }\end{array}$ & Withdrawal rate (\%) \\
\hline \multicolumn{2}{|c|}{ Pension deferral not possible } & \\
\hline Canada & 160 & 15 \\
\hline Greece & 116 & Full \\
\hline Denmark & 50 & 60 \\
\hline Austria & 30 & Full \\
\hline Belgium & 33 & 100 \\
\hline Norway & 18 & 50 \\
\hline Australia & 8 & 50 \\
\hline Ireland & None & Full \\
\hline Portugal & None & Full \\
\hline Spain & None & Full \\
\hline \multicolumn{2}{|c|}{ Pension deferral possible } & \\
\hline Italy & 23 & 100 \\
\hline Japan & $17-90 / 90$ & 20/full \\
\hline United States & 38 & $33-50$ \\
\hline \multicolumn{2}{|l|}{ No restrictions } & \\
\hline Finland & France & \\
\hline Germany & Netherlands & \\
\hline New Zealand & Sweden & \\
\hline Switzerland & United Kingdom & \\
\hline
\end{tabular}

Notes: Pension receipt in Ireland, Portugal and Spain conditional on withdrawal from work; France conditional on withdrawal from normal work. Pension withdrawn at a 100 per cent rate between 29 and 33 per cent of average earnings in Belgium. Italy gives a higher disregard for self-employment incomes (which are an important income source). Australia has a means-tested social security system.

Source: updated from Blöndal and Scarpetta (1998). 
Table 2: Sample sizes

\begin{tabular}{|l|l|ll|ll|}
\hline & & Pre-reform & & Post-reform & \\
& & All & Employed & All & Employed \\
\hline Treatment & Men aged 65-69 & 2111 & 160 & 1713 & 128 \\
Control 1 & Men aged 60-64 & 2185 & 888 & 1558 & 511 \\
Control 2 & Men aged 70-74 & 1573 & 77 & 1371 & 67 \\
\hline Treatment & Women aged 60-64 & 2697 & 450 & 1916 & 338 \\
Control 1 & Women aged 55-59 & 2399 & 1125 & 1718 & 838 \\
Control 2 & Women aged 65-69 & 2576 & 134 & 2017 & 119 \\
\hline
\end{tabular}

Table 3: Participation and hours, before and after the reform

\begin{tabular}{|c|c|c|c|c|c|}
\hline & $\begin{array}{l}\text { Partici } \\
\text { Pre }\end{array}$ & $(\%)$ & $\begin{array}{l}\text { Hours }(>0) \\
\text { Mean Pre }\end{array}$ & Mean Post & $\begin{array}{l}\text { Rank sum } \\
\text { Test }\end{array}$ \\
\hline Men 65-69 & 7.58 & 7.47 & 22.43 & $26.27^{*}$ & 2.266 \\
\hline Men 60-64 & 40.64 & $32.80 *$ & 40.62 & 40.35 & 0.560 \\
\hline Men 70-74 & 4.90 & 4.89 & 17.81 & 18.40 & 1.041 \\
\hline Women 60-64 & 16.39 & 17.64 & 21.06 & $22.89 *$ & 1.611 \\
\hline Women 55-59 & 46.89 & 48.78 & 27.09 & 27.06 & 0.407 \\
\hline Women 65-69 & 5.20 & 5.90 & 15.32 & 16.59 & 0.802 \\
\hline
\end{tabular}

* change significant at 5 per cent level 
Table 4: Regression results (men)

\begin{tabular}{|c|c|c|c|c|c|c|}
\hline \multirow[b]{2}{*}{ Control groups } & \multicolumn{2}{|c|}{$\begin{array}{l}\text { Tobit-hours worked per } \\
\text { week }\end{array}$} & \multicolumn{2}{|c|}{$\begin{array}{l}\text { Probit - worked more } \\
\text { than } 40 \text { hours }\end{array}$} & \multicolumn{2}{|c|}{ Tobit - weekly earnings } \\
\hline & $\begin{array}{l}\text { Older and } \\
\text { younger }\end{array}$ & Older only & $\begin{array}{l}\text { Older and } \\
\text { younger }\end{array}$ & Older only & $\begin{array}{l}\text { Older and } \\
\text { younger }\end{array}$ & Older only \\
\hline Treatment group & $\begin{array}{l}4.121^{* *} \\
(1.334)\end{array}$ & $\begin{array}{l}3.594^{*} \\
(1.887)\end{array}$ & $\begin{array}{l}0.208 * * \\
(0.082)\end{array}$ & $\begin{array}{l}0.080^{*} \\
(0.047)\end{array}$ & $\begin{array}{l}14.18 \\
(12.27)\end{array}$ & $\begin{array}{c}13.93 \\
(15.54)\end{array}$ \\
\hline Younger control & $\begin{array}{l}22.248^{* *} \\
(1.000)\end{array}$ & - & $\begin{array}{l}0.488 * * \\
(0.033)\end{array}$ & - & $\begin{array}{l}148.51 * * \\
(12.37)\end{array}$ & - \\
\hline $\begin{array}{l}\text { Post-reform } \\
\text { dummy }\end{array}$ & $\begin{array}{l}-0.294 \\
(0.611)\end{array}$ & $\begin{array}{l}0.778 \\
(2.246)\end{array}$ & $\begin{array}{l}-0.018 \\
(0.027)\end{array}$ & $\begin{array}{l}-0.035 \\
(0.076)\end{array}$ & $\begin{array}{l}-15.51 * * \\
(7.51)\end{array}$ & $\begin{array}{l}-13.64 \\
(18.50)\end{array}$ \\
\hline $\begin{array}{l}\text { Treatment** } \\
\text { Dummy }\end{array}$ & $\begin{array}{l}4.150 * * \\
(1.474)\end{array}$ & $\begin{array}{l}3.130 \\
(2.760)\end{array}$ & $\begin{array}{l}0.227^{* *} \\
(0.066)\end{array}$ & $\begin{array}{l}0.176^{*} \\
(0.113)\end{array}$ & $\begin{array}{l}42.36 * * \\
(18.14)\end{array}$ & $\begin{array}{l}40.12 * \\
(22.74)\end{array}$ \\
\hline No. obs & 1781 & 429 & 1781 & 429 & 1781 & 429 \\
\hline Log likelihood & -6836.21 & -1722.49 & -1108.85 & -161.70 & -11301.9 & -2627.09 \\
\hline \multicolumn{7}{|c|}{$\begin{array}{l}\text { Standard errors in parentheses. The regressions control for education, marital status, presence of children } \\
\text { in the household, spouse's age, employment and education. } \\
\text { Earnings are adjusted by a wage index calculated using FES data for male employees aged } 20-64 \text {. } \\
* \text { change significant at } 10 \text { per cent level } * * \text { change significant at } 5 \text { per cent level }\end{array}$} \\
\hline
\end{tabular}

Table 5: Regression results (women)

\begin{tabular}{|c|c|c|c|c|c|c|}
\hline \multirow[b]{2}{*}{ Control groups } & \multicolumn{2}{|c|}{$\begin{array}{l}\text { Tobit-hours worked per } \\
\text { week }\end{array}$} & \multicolumn{2}{|c|}{$\begin{array}{l}\text { Probit - worked more } \\
\text { than } 40 \text { hours }\end{array}$} & \multicolumn{2}{|c|}{ Tobit - weekly earnings } \\
\hline & $\begin{array}{l}\text { Older and } \\
\text { younger }\end{array}$ & Older only & $\begin{array}{l}\text { Older and } \\
\text { younger }\end{array}$ & Older only & $\begin{array}{l}\text { Older and } \\
\text { younger }\end{array}$ & Older only \\
\hline Treatment group & $\begin{array}{l}5.214^{* *} \\
(1.026)\end{array}$ & $\begin{array}{l}6,288 * * \\
(1.266)\end{array}$ & $\begin{array}{l}0.172 * * \\
(0.048)\end{array}$ & $\begin{array}{l}0.171 * * \\
(0.040)\end{array}$ & $\begin{array}{l}21.98^{* * *} \\
(6.15)\end{array}$ & $\begin{array}{l}33.54 * * \\
(6.74) \\
\end{array}$ \\
\hline Younger control & $\begin{array}{l}11.430^{* *} \\
(0.860)\end{array}$ & - & $\begin{array}{l}0.372 * * \\
(0.033)\end{array}$ & - & $\begin{array}{l}54.07 * * \\
(5.15)\end{array}$ & - \\
\hline $\begin{array}{l}\text { Post-reform } \\
\text { dummy }\end{array}$ & $\begin{array}{l}-0.186 \\
(0.584) \\
\end{array}$ & $\begin{array}{l}2.070 \\
(1.597)\end{array}$ & $\begin{array}{l}-0.029 \\
(0.024)\end{array}$ & $\begin{array}{l}-0.070 \\
(0.065)\end{array}$ & $\begin{array}{l}-25.35^{* *} \\
(3.50)\end{array}$ & $\begin{array}{l}-1.94 \\
(8.50)\end{array}$ \\
\hline $\begin{array}{l}\text { Treatment* } \\
\text { Dummy }\end{array}$ & $\begin{array}{l}2.350 * * \\
(1.082)\end{array}$ & $\begin{array}{l}-0.298 \\
(1.850)\end{array}$ & $\begin{array}{l}0.103 * * \\
(0.046)\end{array}$ & $\begin{array}{l}0.018 \\
(0.071)\end{array}$ & $\begin{array}{l}23.83 * * \\
(6.48)\end{array}$ & $\begin{array}{l}-0.41 \\
(9.84)\end{array}$ \\
\hline No. obs & 2694 & 984 & 2694 & 984 & 2694 & 984 \\
\hline Log likelihood & -10587.2 & -3877.03 & -1681.54 & -546.48 & -15410.0 & -5522.09 \\
\hline \multicolumn{7}{|c|}{$\begin{array}{l}\text { Standard errors in parentheses. The regressions control for education, marital status, presence of children } \\
\text { in the household, spouse's age, employment and education. } \\
\text { Earnings are adjusted by a wage index calculated using FES data for male employees aged } 20-64 \text {. } \\
* \text { change significant at } 10 \text { per cent level } * * \text { change significant at } 5 \text { per cent level }\end{array}$} \\
\hline
\end{tabular}


Fig. 1: Operation of the Earnings Rule

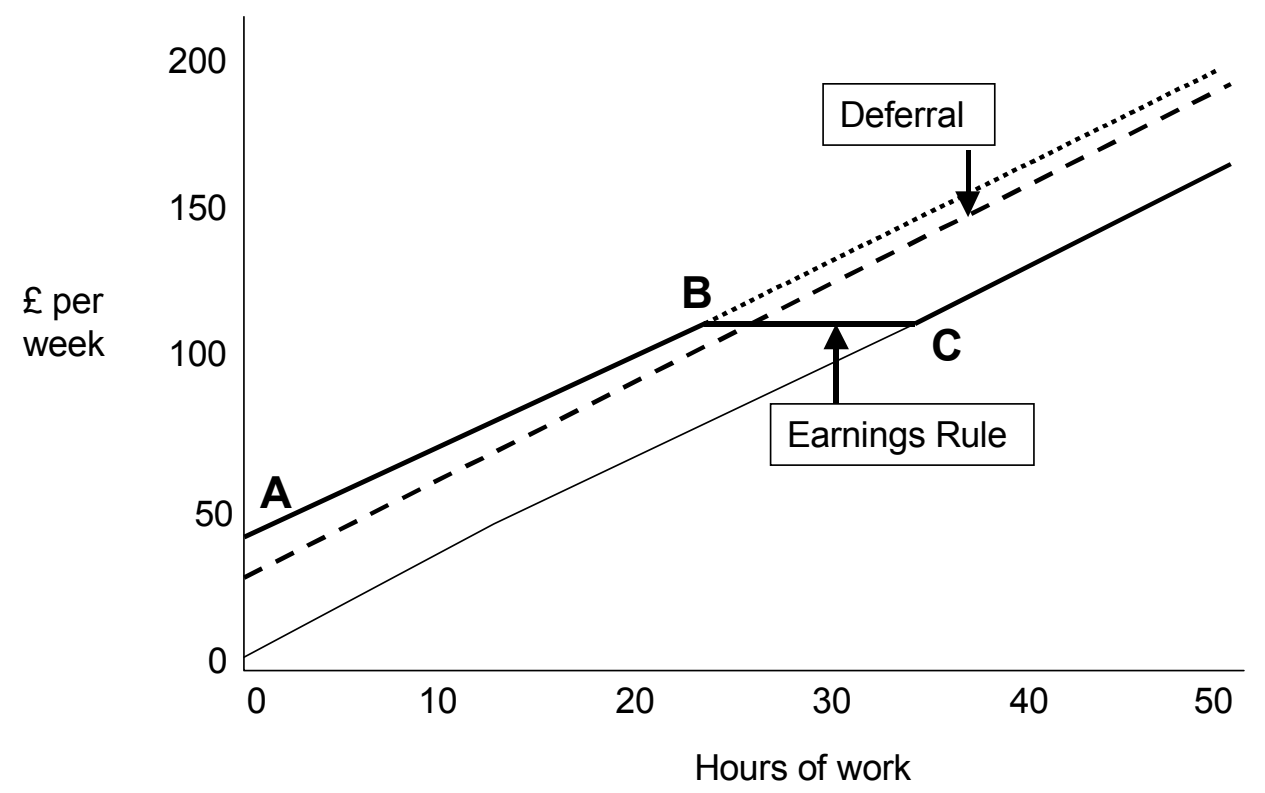


Fig. 2A Distribution of male weekly earnings
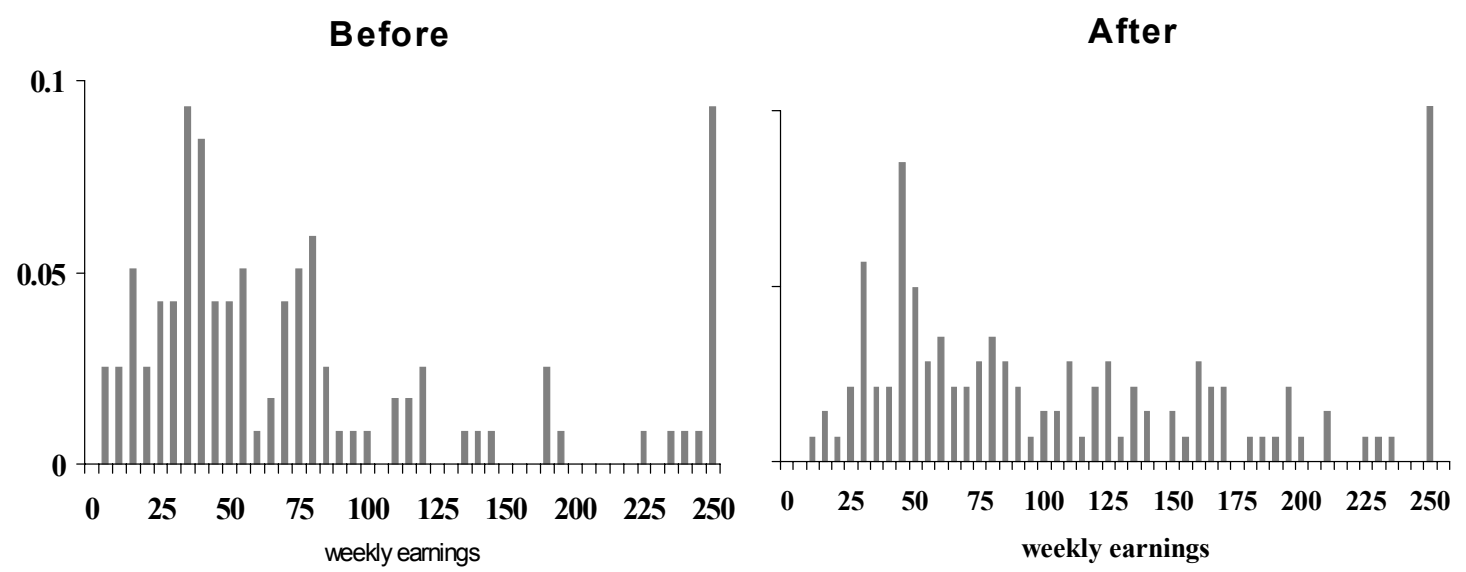

Apr86-Sep89

Oct89-Mar94

Fig. 2B Distribution of female weekly earnings

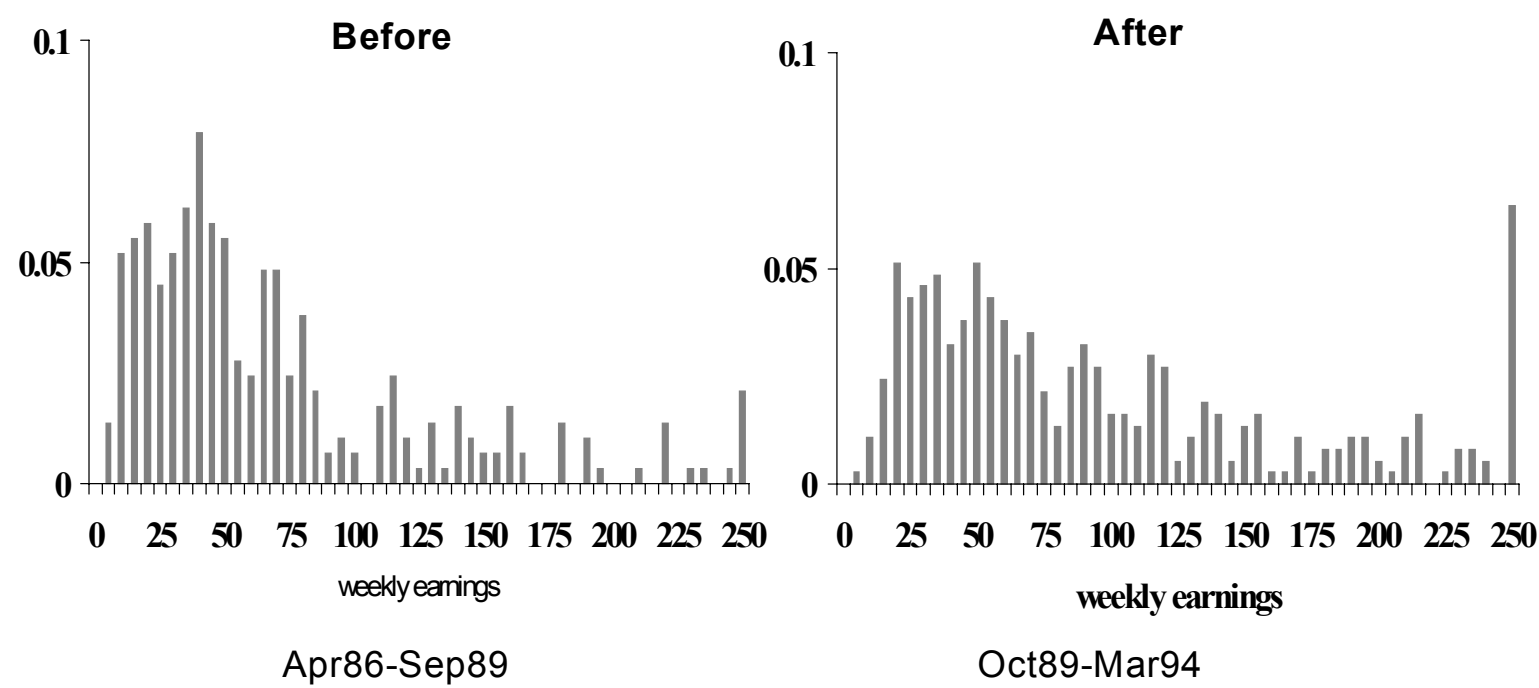


Figure 3: Proportion of men in receipt of deferred pension, by cohort

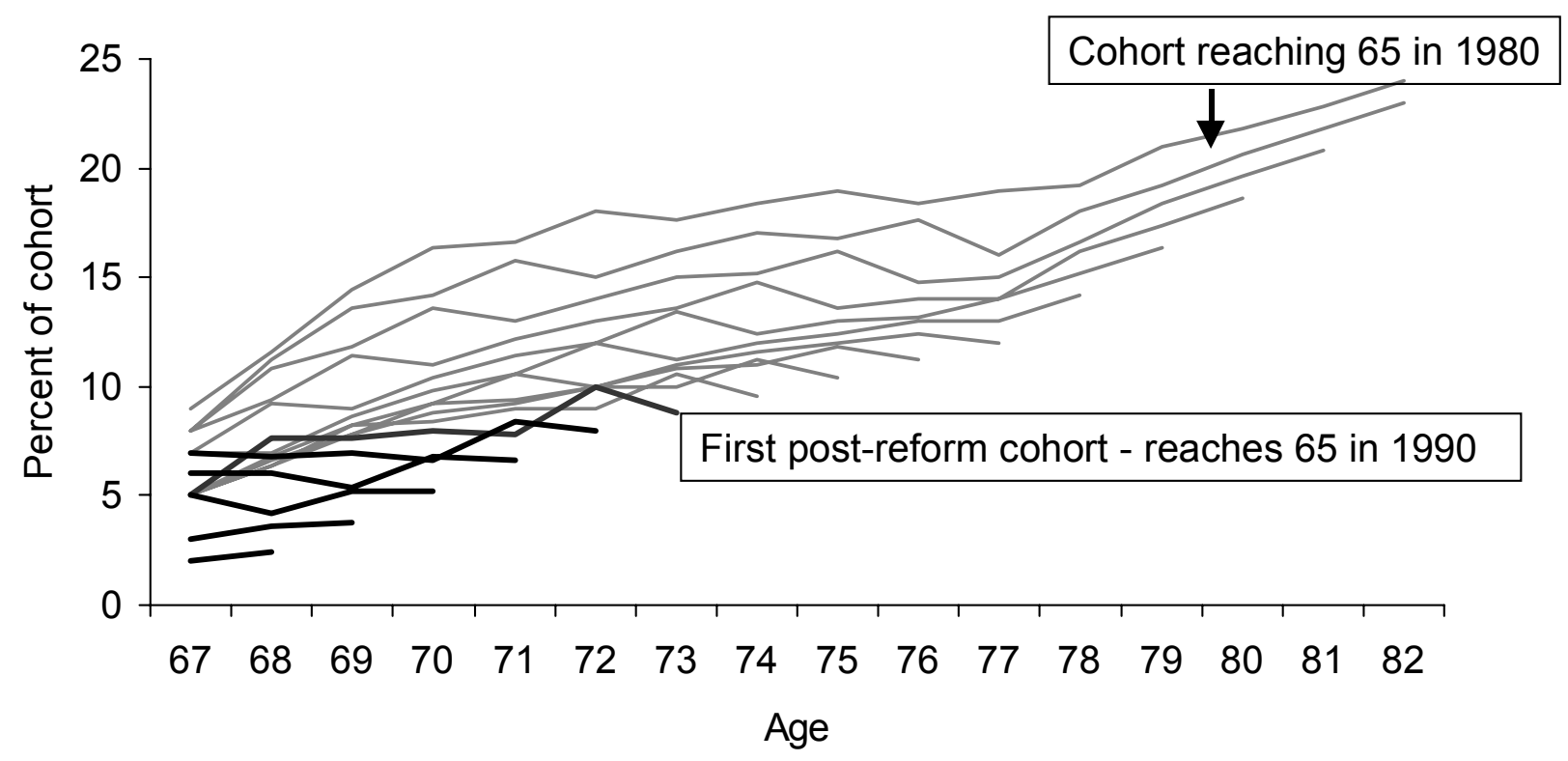




\section{References}

Angrist. J. and Krueger, A. (1999) Empirical strategies in labor economics, 12771365 in O. Ashenfelter and D. Card (eds) Handbook of Labor Economics, Volume 3, Elsevier Science B.V.

Baker, M. and Benjamin, D. (1999) How do retirement tests affect the labour supply of older men? Journal of Public Economics, 71, 27-51.

Blöndal, S. and Scarpetta, S. (1998) The retirement decision in OECD countries, Ageing Working Paper 1-4, Organisation for Economic Co-operation and Development: Paris.

Blundell, R., Duncan, A., McCrae, J. and Meghir, C. (2000) The labour market impact of the working families' tax credit, Fiscal Studies, 21 (March), 75-104.

Blundell, R., Duncan, A. and Meghir, C. (1998) Estimating labour supply responses using tax reforms, Econometrica, 66 (July), 827-862.

Blundell, R. and Johnson, P. (1999) Pensions and retirement in the United Kingdom, 403-435 in J. Gruber and D. Wise (eds) (1999).

Burtless, G. and Moffitt, R. (1985) The joint choice of retirement age and postretirement hours of work, Journal of Labor Economics, 3, 209-236.

Disney, R. (1999) Why have older men stopped working? 58-74 in P. Gregg and J. Wadsworth (eds) The State of Working Britain, Manchester University Press.

Eissa, N. and Hoynes, H. (1998) The Earned Income Tax Credit and the labor supply of married couples, National Bureau of Economic Research Working Paper W6856.

Eissa, N. and Leibman, J. (1996) Labor supply response to the Earned Income Tax Credit, Quarterly Journal of Economics, 111, 605-37.

Friedberg, L. (1998) The social security earnings test and labor supply of older men, 121-150 in J. Poterba (ed) Tax Policy and the Economy, 12, Cambridge: MIT Press.

Friedberg, L. (2000) The labor supply effects of the social security earnings test, Review of Economics and Statistics, 82 (February), 48-63.

Gruber, J. and Oszag, P. (2000) Does the social security earnings test affect labor supply and benefits receipt? mimeo, MIT, September.

Gruber, J. and Wise, D. (eds) (1999) Social Security and Retirement around the World, University of Chicago Press, for National Bureau of Economic Research.

Gustman, A. and Steinmeier, T. (1986) A structural retirement model, Econometrica, $54,555-584$.

Hurd, M. (1996) The effect of labor market rigidities on the labor force behavior of older men, 11-58 in D. Wise (ed) Advances in the Economics of Aging, University of Chicago Press, for National Bureau of Economic Research.

Johnson, R. (2000) The effect of old age insurance on male retirement: Evidence from historical cross-country data, Federal Reserve Bank of Kansas City, Research Division, Working Paper 0-09. 
Leonesio, M. (1990) Effects of the social security test on the labor market activity of older Americans: A review of the evidence, Social Security Bulletin, 53, 2-21.

MaCurdy, T, Green, D. and Paarsch, H. (1990) Assessing empirical approaches for analyzing taxes and labor supply, Journal of Human Resources, 25, 415-490.

OECD (1996) Policy implications of Ageing: A Critical Policy Challenge, Social Policy Studies No. 20, Organisation for Economic Co-operation and Development: Paris.

Whitehouse, E. (1990) The abolition of the pension 'earnings rule', Fiscal Studies, 11 (August), 55-70.

Zabalza, A., Pissarides, C. and Barton, M. (1980) Social security and the choice between full-time work, part-time work, and retirement, Journal of Public Economics, 14, 245-276. 


\section{Footnotes}

\footnotetext{
University of Nottingham, and Institute for Fiscal Studies, London. Corresponding author: School of Economics, University of Nottingham, NG7 2RD, UK; email: richard.disney@nottingham.ac.uk

Financial Services Authority

1 Indeed, as Johnson (2000) has recently restated, the existence of some form of earnings test and 'actuarially unfair' deferral are required if the public pension programme is to act as an implicit tax on continued work late in life.
}

2 The Senior Citizens' Freedom to Work Act, signed in law, April 7, 2000. The test remains in force for individuals aged 62 to 64 in the US, with a modified test for the year the individual reaches 65 .

3 The earnings rule also contained a notional limit on exempt weekly hours but in practice, the earnings limit seems to have been the binding constraint.

4 This conclusion has to be slightly qualified if there are substantial fixed costs of work and/or if current labour supply decisions take account of future retirement behaviour. In such cases, hours and participation should be simultaneously modelled by suitable techniques. We do not handle this explicitly in this particular paper, although we account for the censoring of hours and earnings at zero.

5 The deferral rate had been raised to $7.5 \%$ in the years leading up to 1989 and was subsequently raised to $10 \%$ in 1995 .

6 Similar issues have been noted in the analysis of in-work benefits to low income married couples: see, again, Blundell et al (2000) for the UK, and Eissa and Hoynes (1998) for the US.

7 For example, in the studies of the Earned Income Tax Credit cited above (Eissa and Leibman, 1996; Eissa and Hoynes, 1998), amongst others.

8 There were however some transition provisions which were equivalent to actuarial fair deferral, not discussed by Baker and Benjamin. We owe this point to Richard Johnson (see Johnson, 2000).

${ }^{9}$ We ignore the fourth possible option - retire and defer pension receipt - by assuming no other available source of income.

10 This might, in turn, be affected by the decision whether to carry on working, but this is not something we consider here.

${ }^{11}$ Pension income is assumed not to be taxed since, in the UK, the value of the individual's personal tax allowance is at least as great as the value of the basic state pension.

${ }^{12}$ For simplicity, ignore the small segment of the budget constraint with a 50 per cent withdrawal rate.

${ }^{13}$ There could be a potential problem if we used data from after 1994 when the older cohort of people would include those people who were in the treatment age range when the reform was made. If there were employment dynamics such that hours and earnings decisions taken when 65-69 affected hours and earnings decisions when 70-74 then the older group would not be a proper control.

${ }^{14}$ We attempted to increase sample size by splicing in additional data from the General Household Survey, but inconsistent data definitions precluded this strategy yielding useful results.

15 One might argue for using a Heckman procedure in conditioning hours on participation: however, see the discussion above, and footnote 2 in particular.

${ }^{16} \mathrm{We}$ experimented with various cut-offs of hours to capture any income effects inducing reductions in hours among full-time workers, without success. It is possible of course that earnings cut-offs, rather than hours, might find evidence of such opposite effects and indeed Friedberg (2000) does find very small such effects.

${ }^{17}$ Given the argument in Section 2, it would be nice to pin down the possible different behaviour of wives, single women (never married versus widows and divorcees). Small sample sizes preclude this.

${ }^{18}$ A similar pattern is observed for women. Results available on request. 
Our papers can be downloaded at:

http://cerp.unito.it

CeRP Working Paper Series:

\begin{tabular}{|c|c|c|}
\hline $\mathrm{N}^{\circ} 1 / 00$ & Guido Menzio & Opting Out of Social Security over the Life Cycle \\
\hline $\mathrm{N}^{\circ} 2 / 00$ & $\begin{array}{l}\text { Pier Marco Ferraresi } \\
\text { Elsa Fornero }\end{array}$ & $\begin{array}{l}\text { Social Security Transition in Italy: Costs, Distorsions } \\
\text { and (some) Possible Correction }\end{array}$ \\
\hline $\mathrm{N}^{\circ} 3 / 00$ & $\begin{array}{l}\text { Emanuele Baldacci } \\
\text { Luca Inglese }\end{array}$ & $\begin{array}{l}\text { Le caratteristiche socio economiche dei pensionati in } \\
\text { Italia. Analisi della distribuzione dei redditi da } \\
\text { pensione (only available in the Italian version) }\end{array}$ \\
\hline $\mathrm{N}^{\circ} 4 / 01$ & Peter Diamond & Towards an Optimal Social Security Design \\
\hline $\mathrm{N}^{\circ} 5 / 01$ & Vincenzo Andrietti & $\begin{array}{l}\text { Occupational Pensions and Interfirm Job Mobility in } \\
\text { the European Union. Evidence from the ECHP Survey }\end{array}$ \\
\hline$N^{\circ} 6 / 01$ & Flavia Coda Moscarola & $\begin{array}{l}\text { The Effects of Immigration Inflows on the } \\
\text { Sustainability of the Italian Welfare State }\end{array}$ \\
\hline $\mathrm{N}^{\circ} 7 / 01$ & Margherita Borella & $\begin{array}{l}\text { The Error Structure of Earnings: an Analysis on } \\
\text { Italian Longitudinal Data }\end{array}$ \\
\hline $\mathrm{N}^{\circ} 8 / 01$ & Margherita Borella & $\begin{array}{l}\text { Social Security Systems and the Distribution of } \\
\text { Income: an Application to the Italian Case }\end{array}$ \\
\hline $\mathrm{N}^{\circ} 9 / 01$ & Hans Blommestein & $\begin{array}{l}\text { Ageing, Pension Reform, and Financial Market } \\
\text { Implications in the OECD Area }\end{array}$ \\
\hline $\mathrm{N}^{\circ} 10 / 01$ & $\begin{array}{l}\text { Vincenzo Andrietti and } \\
\text { Vincent Hildebrand }\end{array}$ & $\begin{array}{l}\text { Pension Portability and Labour Mobility in the United } \\
\text { States. New Evidence from the SIPP Data }\end{array}$ \\
\hline $\mathrm{N}^{\circ} 11 / 01$ & $\begin{array}{l}\text { Mara Faccio and } \\
\text { Ameziane Lasfer }\end{array}$ & $\begin{array}{l}\text { Institutional Shareholders and Corporate Governance: } \\
\text { The Case of UK Pension Funds }\end{array}$ \\
\hline $\mathrm{N}^{\circ} 12 / 01$ & Roberta Romano & $\begin{array}{l}\text { Less is More: Making Shareholder Activism a } \\
\text { Valuable Mechanism of Corporate Governance }\end{array}$ \\
\hline $\mathrm{N}^{\circ} 13 / 01$ & Michela Scatigna & $\begin{array}{l}\text { Institutional Investors, Corporate Governance and } \\
\text { Pension Funds }\end{array}$ \\
\hline
\end{tabular}


$\mathrm{N}^{\circ} 14 / 01$ Thomas H. Noe

$\mathrm{N}^{\circ} 15 / 01 \quad$ Estelle James

$\mathrm{N}^{\circ} 16 / 01 \quad$ Estelle James and Xue Song

$N^{\circ} 17 / 02$ Richard Disney and Sarah Smith
Investor Activism and Financial Market Structure

How Can China Solve ist Old Age Security Problem? The Interaction Between Pension, SOE and Financial Market Reform

Annuities Markets Around the World: Money's Worth and Risk Intermediation

The Labour Supply Effect of the Abolition of the Earnings Rule for Older Workers in the United Kingdom 